\title{
RADIOCARBON DATING OF PLEISTOCENE FAUNA AND FLORA FROM STARUNIA, SW UKRAINE
}

\author{
T Kuc ${ }^{1,2} \bullet \mathrm{K} \mathrm{Różański}^{1} \bullet \mathrm{M} \mathrm{J} \mathrm{Kotarba}^{3} \cdot \mathrm{T} \mathrm{Goslar}^{4,5} \bullet \mathrm{H} \mathrm{Kubiak}^{6}$
}

ABSTRACT. New attempts are presented to determine the age of large Pleistocene mammals excavated at Starunia, $\sim 130 \mathrm{~km}$ southeast of Lviv, Ukraine. This remarkable discovery made at the beginning of the 20th century included a complete carcass of woolly rhinoceros (No. 2), fragments of 3 woolly rhinoceroses (Nos. 1, 3, and 4) and remnants of numerous specimens of other fossil fauna and flora. Although attempts to date paleontological findings from Starunia site go back to the early 1970s, the results obtained before 2006 are somewhat misleading, mostly due to unresolved contamination problems. Comprehensive cleaning of the samples adopted in the framework of this study was aimed at removal of 2 potential sources of contamination: (i) radiocarbon-free hydrocarbons abundant at the burial site; and (ii) allochthonous organic materials containing contemporary carbon that were used in the past during preservation of the dated specimens. Two types of samples have been analyzed for their ${ }^{14} \mathrm{C}$ content in the framework of the present study: (i) fragments of bones and teeth collected from specimens stored or exposed in the Natural History museums in Lviv and Kraków; and (ii) samples of terrestrial macrofossils retrieved from sediment cores obtained during the 2007-2008 field campaigns in the Starunia area. ${ }^{14} \mathrm{C}$ analyses of collagen were supplemented by measurements of its elemental $\mathrm{C} / \mathrm{N}$ ratio and ${ }^{13} \mathrm{C} /{ }^{12} \mathrm{C}$ and ${ }^{15} \mathrm{~N} /{ }^{14} \mathrm{~N}$ isotope ratios. Three ${ }^{14} \mathrm{C}$ dates obtained for rhinoceros No. 2 span the age range from 35.3 to $40.0 \mathrm{ka} \mathrm{BP}$, in agreement with the minimum age estimated from macrofossils. The mean value of $37.7 \pm 1.7 \mathrm{ka}$ BP falls in the range of ages reported for big Pleistocene mammals from other locations in Europe. The bones of rhinoceros No. 3, which were found in close vicinity to those of rhinoceros No. 2, reveal a ${ }^{14} \mathrm{C}$ age of $36.7 \pm 0.6 \mathrm{ka} \mathrm{BP}$. The $\delta^{15} \mathrm{~N}$ and $\delta^{13} \mathrm{C}$ values obtained for collagen extracted from bones and teeth belonging to rhinoceroses Nos. 1, 2, and 3 are in a broad agreement with analogous literature data for large Pleistocene mammals found in other sites in Europe, North America, and Siberia.

\section{INTRODUCTION}

The discovery of large Pleistocene mammals in the Starunia ozocerite mine $\sim 130 \mathrm{~km}$ southeast of Lviv, Ukraine (Figure 1) was a spectacular scientific event at the onset of 20th century (e.g. Alexandrowicz 2004, 2005). The initial discovery was made in 1907 when fragments of mammoth and woolly rhinoceros (later named No. 1) were excavated at depths of 12.5 and $17.6 \mathrm{~m}$, respectively (Bayger et al. 1914). In 1929, the Polish Academy of Arts and Sciences organized a dedicated expedition to the site and a complete woolly rhinoceros carcass (No. 2) was discovered at $12.5 \mathrm{~m}$ depth, $\sim 3.3 \mathrm{~m}$ northwest of the site of initial findings. A unique combination of oil and brine into which the animal had most probably sunk was responsible for the almost perfect preservation of this specimen (Kotarba 2002; Kotarba et al. 2009). Shortly afterwards, bone remnants of 2 more rhinoceroses (Nos. 3 and 4) were found at this site, in addition to numerous specimens of other fossil fauna and flora (Kubiak and Drygant 2005). The remnants of fossil fauna discovered in Starunia in 1907 are presently exhibited in the Natural History Museum of the National Academy of Sciences of Ukraine in Lviv, Ukraine, whereas the specimens excavated in 1929 are displayed at the Natural History Museum and in the Institute of Systematics and Evolution of Animals of the Polish Academy of Sciences, both in Kraków, Poland (Table 1).

The remnants of fossil flora and fauna discovered in Starunia were subjected to various scientific investigations going back to the early 20th century. These studies were mostly aimed at identification and classification of the findings, assessment of their age, and characterization of the local environ-

\footnotetext{
${ }^{1}$ AGH University of Science and Technology, Faculty of Physics and Applied Computer Science, Al. Mickiewicza 30, 30-059 Kraków, Poland.

${ }^{2}$ Corresponding author. Email: kuc@agh.edu.pl.

${ }^{3}$ AGH University of Science and Technology, Faculty of Geology, Geophysics and Environmental Protection, Al. Mickiewicza 30, 30-059 Kraków, Poland.

${ }^{4}$ Poznań Radiocarbon Laboratory, Foundation of the Adam Mickiewicz University, Rubież 46, 61-612 Poznań, Poland.

${ }^{5}$ Faculty of Physics, Adam Mickiewicz University, Umultowska 85, 61-614 Poznań, Poland.

${ }^{6}$ Institute of Systematics and Evolution of Animals, Polish Academy of Sciences, Sławkowska 17, 31-016 Kraków, Poland.
} 


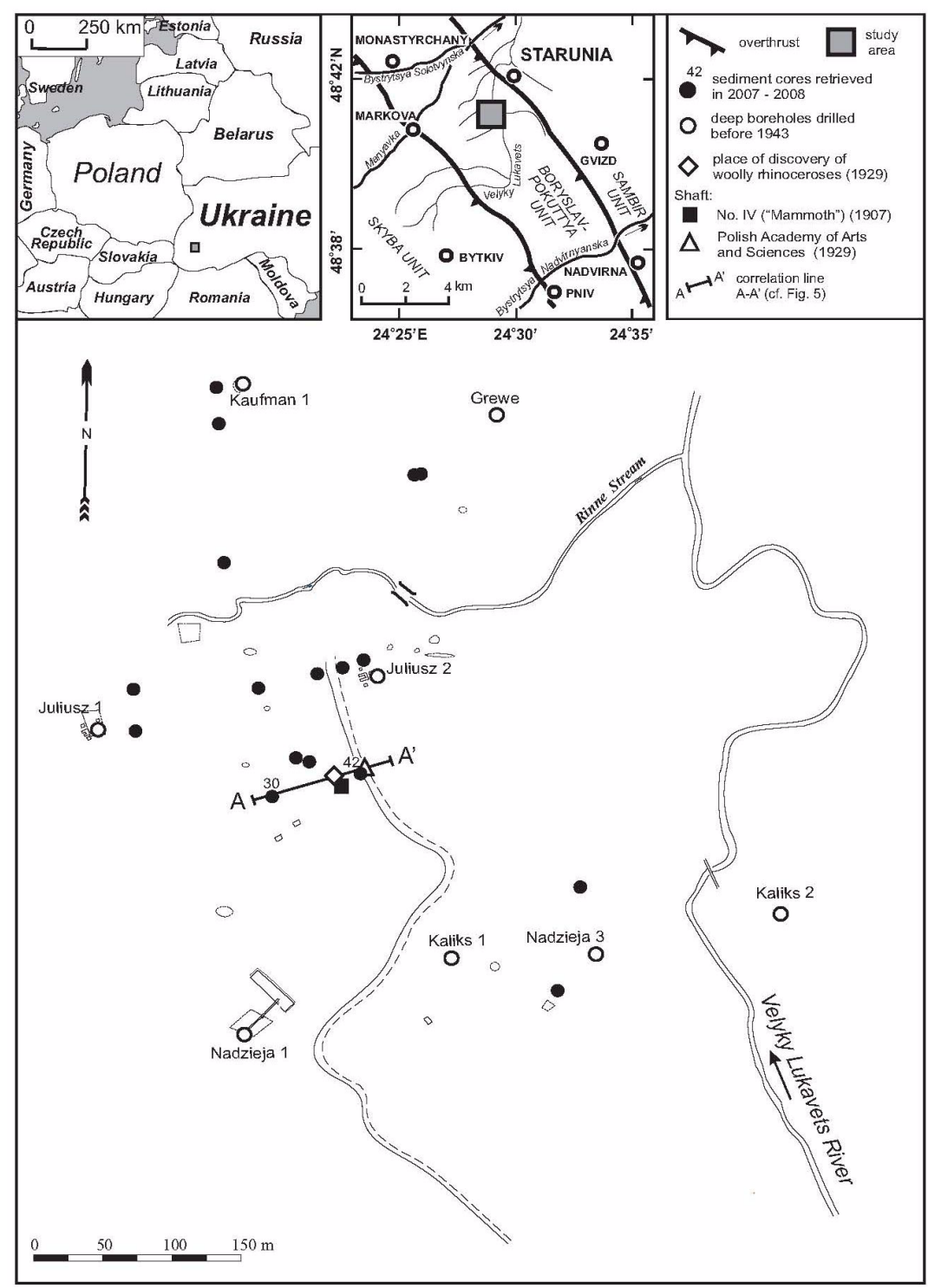

Figure 1 Sketch map of the Starunia paleontological site (Carpathian region, Ukraine) showing locations of the discovery of woolly rhinoceroses and that of boreholes from which microfossils were extracted from sediment cores for ${ }^{14} \mathrm{C}$ dating.

ment (Alexandrowicz 2004; Sokołowski et al. 2009; Stachowicz-Rybka et al. 2009 and references therein). In 2004-2005, comprehensive studies including geophysical survey, microbiological studies, geochemical studies of hydrocarbon source rocks from outcrops and drill cores, isotopic and chemical investigations of oils and natural gases from deep accumulations and surface seeps, as well as radiocarbon dating of fauna remnants in the Starunia area have been carried out (Kotarba 2005). The work continued during 2006-2009 (Kotarba 2009a,b) with an emphasis on contouring and identifying the internal structure of Pleistocene sediments hosting the remnants of fossil flora and fauna, localizing Pleistocene lakes and marshes in the area, and characterizing properties of the depositional environment. 
Table 1 Woolly mammoth and woolly rhinoceroses found in Starunia excavation area and ${ }^{14} \mathrm{C}$ dating laboratories engaged in dating of those specimens (Kuc et al. 2005).

\begin{tabular}{|c|c|c|c|}
\hline Specimen & Remarks & Place of storage & $\begin{array}{l}\text { Dating } \\
\text { laboratory }\end{array}$ \\
\hline $\begin{array}{l}\text { Mammuthus primigenius } \\
\text { (woolly mammoth) }\end{array}$ & $\begin{array}{l}\text { Parts of skeleton, skin, muscle, } \\
\text { shaft IV; Depth: } 12.5 \mathrm{~m}^{\mathrm{b}} \text {; } \\
\text { Found: autumn } 1907\end{array}$ & $\begin{array}{l}\text { Museum of Natural Sciences, } \\
\text { Lviv, Ukraine }\end{array}$ & Gd, GIN, Poz \\
\hline $\begin{array}{l}\text { Coelodonta antiquitatis } \\
\text { (woolly rhinoceros No. 1) }\end{array}$ & $\begin{array}{l}\text { Anterior part of body, shaft IV; } \\
\text { Depth: } 17.5 \mathrm{~m}^{\text {b}} \text {; Found: No- } \\
\text { vember } 1907\end{array}$ & $\begin{array}{l}\text { Museum of Natural Sciences, } \\
\text { Lviv, Ukraine }\end{array}$ & $\mathrm{Gd}, \mathrm{OxA}$ \\
\hline $\begin{array}{l}\text { Coelodonta antiquitatis } \\
\text { (woolly rhinoceros No. 2) }\end{array}$ & $\begin{array}{l}\text { Complete specimen, under- } \\
\text { ground gallery; Depth: } 12.5 \mathrm{~m} \text {; } \\
\text { Found: } 23 \text { October } 1929\end{array}$ & $\begin{array}{l}\text { Polish Academy of Sciences, } \\
\text { Kraków, Poland }\end{array}$ & SI, Hv, Poz, KR \\
\hline $\begin{array}{l}\text { Coelodonta antiquitatis } \\
\text { (woolly rhinoceros No. } 3 \text { ) }\end{array}$ & $\begin{array}{l}\text { Bones, major part of skeleton, } \\
\text { underground gallery; Depth: } \\
11.0 \mathrm{~m}^{\text {b }} \text {; Found: } 1929 \text {, after } 23 \\
\text { October, exact date unknown }\end{array}$ & $\begin{array}{l}\text { Polish Academy of Sciences, } \\
\text { Kraków, Poland }\end{array}$ & Poz, KR \\
\hline $\begin{array}{l}\text { Coelodonta antiquitatis } \\
\text { (woolly rhinoceros No. } 4 \text { ) }\end{array}$ & $\begin{array}{l}\text { Bones, small fragments, under- } \\
\text { ground gallery; Depth: } 11.0 \mathrm{~m}^{\text {b}} \text {; } \\
\text { Found: } 1929 \text {, after } 23 \text { October, } \\
\text { exact date unknown }\end{array}$ & $\begin{array}{l}\text { Polish Academy of Sciences, } \\
\text { Kraków, Poland }\end{array}$ & $\mathrm{Poz}$ \\
\hline
\end{tabular}

${ }^{a}$ Lab codes: Gd-Radiocarbon Laboratory, Silesian University of Technology, Poland; GIN-Geological Institute Russian Academy of Science, Russia; Hv- ${ }^{14} \mathrm{C}$-und ${ }^{3} \mathrm{H}$-Laboratorium, Niedersächsiches Landesamt für Bodenforschung, Hannover, Germany; KR-Kraków Radiocarbon Laboratory, AGH University of Science and Technology, Poland; OxA-Oxford Radiocarbon Accelerator Unit, Research Laboratory for Archaeology and History of Art., England; Poz-Poznań Radiocarbon Laboratory, Foundation of the Adam Mickiewicz University, Poland; SI-Smithsonian Institution, Radiation Biology Laboratory, ${ }^{14} \mathrm{C}$ Laboratory, Maryland, USA;

${ }^{b}$ Depth at time of excavation.

Initial attempts to date the mammoth and woolly rhinoceroses remnants from Starunia using ${ }^{14} \mathrm{C}$ go back to the 1970s (Kubiak 1971, 2003). They were performed by various laboratories, on the material obtained either from the specimens exhibited in the Natural History Museum in Kraków or kept in the storeroom of this museum. The results revealed large differences in ${ }^{14} \mathrm{C}$ ages obtained for the same specimens (Table 2), leaving the question of the true age of the dated material open (Kuc et al. 2005).

\section{SITE DESCRIPTION}

Starunia, a small village dating back to the Middle Ages, is situated in the Fore-Carpathian region, close to the city of Ivano-Frankivs'k, about $140 \mathrm{~km}$ southeast of Lviv, Ukraine (Figure 1). It is known as a site rich in mineral resources (Alexandrowicz 2005). The exploitation of earth wax (ozocerite) started there in 1868 and continued until 1960 (Adamenko et al. 2005). The ozocerite is hosted in the Lower Miocene salt-bearing Vorotyshcha Beds, which rest upon the flysch strata of the Boryslav-Pokuttya Unit. The Starunia fold of the Borislav-Pokuttya Unit contains small quantities of oil and gas. To the south and southwest of this fold, both the Paleogene and the Neogene reservoirs of the Boryslav-Pokuttya and Skyba units host large oil and gas fields (Koltun et al. 2005). The Boryslav-Pokuttya Unit is the main oil reservoir of the Carpathian Province (e.g. Kotarba and Koltun 2006). In the Starunia area and its vicinity, 2 tectonic units of the Carpathian Foredeep occur: the Sambir and the Boryslav-Pokuttya units as well as the external part of the Skyba Unit, the latter belonging to the Outer Carpathians (Figure 1).

In the vicinity of Starunia village, there are numerous brine springs (Alexandrowicz 2004; Duliński et al. 2005), which are linked to halite and potassium salt deposits occurring within the Lower 
Miocene salt-bearing Vorotyshcha Beds (Alexandrowicz 2005; Kotarba et al. 2009). In the study area, the salt-bearing clays host both the ozocerite veins and halite. Surface appearances of saturated brines and oil in the Starunia region were a key factor contributing to the excellent preservation of soft tissues of large extinct mammals found in this area. The Upper Pleistocene and Holocene strata in the Starunia area hosting specimens of fossil fauna and flora are represented by channel (gravel, sandy gravel), overbank alluvium (mud, peat, biogenic mud), and colluvium (mud, sandy mud) deposits. Abundant mine wastes are also present in the area. Channel sediments represent mainly material laid down in straight segments of meandering river beds. Most common, fine-grained, distal floodplain sediments are locally up to $10 \mathrm{~m}$ thick and are dominated by massive mud lithofacies, which contain burrows, root hairs, or larger root traces and reed rods (for details see Sokołowski et al. 2009).

Table 2 Summary of ${ }^{14} \mathrm{C}$ ages of remnants of mammoth and woolly rhinoceroses excavated in Starunia, obtained by different laboratories (Kuc et al. 2005).

\begin{tabular}{|c|c|c|c|c|c|}
\hline Dated specimen & Type of tissue dated & $\begin{array}{l}\text { Year of } \\
\text { dating }\end{array}$ & $\begin{array}{l}\text { Dating } \\
\text { method }^{\mathrm{a}}\end{array}$ & $\begin{array}{l}\text { Sample } \\
\text { code }\end{array}$ & $\begin{array}{l}{ }^{14} \mathrm{C} \text { age } \\
(\mathrm{yr} \mathrm{BP})\end{array}$ \\
\hline \multirow{3}{*}{$\begin{array}{l}\text { Mammuthus primigenius } \\
\text { (woolly mammoth) }\end{array}$} & Soft tissue & 2001 & GC & Gd-17077 & $22,610+3400 /-2380$ \\
\hline & $\begin{array}{l}\text { Soft tissue (meat from } \\
\text { asphalt, Sulerzhitsky } \\
\text { 1997) }\end{array}$ & 1997 & LSC & GIN-6633 & $35,100 \pm 1000$ \\
\hline & Bone, part of vertebra & 2005 & AMS & Poz-11347 & $45,000 \pm 2000$ \\
\hline \multirow{2}{*}{$\begin{array}{l}\text { Coelodonta antiquitatis } \\
\text { (woolly rhinoceros No. 1) }\end{array}$} & Bone & 2001 & GC & Gd-16065 & $14,140 \pm 480$ \\
\hline & Part of skull & 2001 & & Gd-17061 & $\begin{array}{l}14,200 \pm 490 \\
\text { (weighted mean: } \\
14,170 \pm 340 \text { ) }\end{array}$ \\
\hline \multirow{3}{*}{$\begin{array}{l}\text { Coelodonta antiquitatis } \\
\text { (woolly rhinoceros No. 2) }\end{array}$} & Soft tissue & 2002 & AMS & OxA-11413 $3^{b}$ & $42,150 \pm 750$ \\
\hline & Soft tissue & 1971 & LSC (?) & SI-642 & $23,000 \pm(\mathrm{ns})$ \\
\hline & $\begin{array}{l}\text { Soft tissue (skin) } \\
\text { collagen? }\end{array}$ & 1974 & $\mathrm{GC}$ & Hv-5989 & $\begin{array}{l}36,250 \pm 815^{\mathrm{c}} \\
23,255 \pm ?(\mathrm{~ns})\end{array}$ \\
\hline \multirow{5}{*}{$\begin{array}{l}\text { Coelodonta antiquitatis } \\
\text { (woolly rhinoceros No. } 3 \text { ) }\end{array}$} & Soft tissue & 2005 & AMS & Poz-11348 & $47,000 \pm 3000$ \\
\hline & Soft tissue & 2005 & LSC & KR-200 & $26,750 \pm 450$ \\
\hline & Bone (collagen) & 2001 & $\mathrm{GC}$ & Gd-15241 & $18,440 \pm 310$ \\
\hline & $\begin{array}{l}\text { Part of a rib (collagen) } \\
\text { (carbonate fraction) }\end{array}$ & 2005 & AMS & $\begin{array}{l}\text { Poz-11349 } \\
\text { Poz-11441 }\end{array}$ & $\begin{array}{l}41,600 \pm 1400 \\
26,590 \pm 190\end{array}$ \\
\hline & Part of a rib (collagen) & 2005 & LSC & KR-201 & $39,700 \pm 2500$ \\
\hline $\begin{array}{l}\text { Coelodonta antiquitatis } \\
\text { (woolly rhinoceros No. } 4 \text { ) }\end{array}$ & $\begin{array}{l}\text { Part of a shoulder-blade } \\
\text { (collagen) }\end{array}$ & 2005 & AMS & Poz-11350 & $40,300 \pm 1200$ \\
\hline
\end{tabular}

aGC: gas counters; LSC: liquid scintillation counters; AMS: accelerator mass spectrometry; ns: not specified.

${ }^{b}$ Dating of rhinoceroses Nos. 1, 3, and 4 (3 samples) failed.

${ }^{\mathrm{c}}$ Dated soft tissue not chemically treated.

\section{DISCOVERY OF LARGE PLEISTOCENE MAMMALS}

In 1907, during mining works conducted in shaft IV (later called "Mammoth shaft") of the old ozocerite mine in Starunia village, fragments of mammoth were found at $12.5 \mathrm{~m}$ depth. Subsequent deepening of the shaft led to discovery of large fragments of woolly rhinoceros (No. 1) comprised 
of the left front part of the body with preserved pieces of skin and flesh. The circumstances of the finding and accompanying artifacts pointed to redeposition of those specimens during filling up the old, abandoned shaft several years earlier.

In June 1929, a dedicated expedition of the Polish Academy of Arts and Sciences was directed to the site where the new shaft was constructed (Figure 1), about $15 \mathrm{~m}$ northeast of the "Mammoth shaft" and a gallery joining both shafts was cut. In October 1929, in another gallery cut in the northwest direction, a complete body of a woolly rhinoceros (No. 2) was found in Quaternary clays at $\sim 12.5 \mathrm{~m}$ depth, lying in upside down position (Stach 1930; Alexandrowicz 2005) directly in contact with Miocene clays. The woolly rhinoceros was discovered $\sim 3.3 \mathrm{~m}$ from "Mammoth shaft" (Figure 1). Later works in the gallery revealed bones of another woolly rhinoceros (No. 3) in a good state of preservation. Those were found $\sim 1.5 \mathrm{~m}$ above the woolly rhinoceros No. 2 , very close to it in a horizontal direction. Subsequent examination revealed that one of the bones belongs undoubtedly to a young specimen. This single bone was recognized and described as belonging to a woolly rhinoceros, named No. 4 (Kubiak 2003).

As a result of the Second World War and subsequent political transformations in the region, remnants of big Pleistocene mammals found at the Starunia site are currently stored in the Natural History museums of 2 cities: Lviv, Ukraine, and Kraków, Poland.

\section{MATERIALS AND METHODS}

Two types of samples have been analyzed for their ${ }^{14} \mathrm{C}$ content in the framework of the present study: (i) fragments of bones and teeth collected from specimens stored or on display in the museums in Lviv (woolly rhinoceros No. 1) and Kraków (woolly rhinoceroses Nos. 2 and 3); and (ii) samples of terrestrial macrofossils retrieved from selected sediment cores obtained during the 20072008 field campaigns in the Starunia area. ${ }^{14} \mathrm{C}$ analyses of collagen were supplemented by measurements of elemental $\mathrm{C} / \mathrm{N}$ ratios and ${ }^{13} \mathrm{C} /{ }^{12} \mathrm{C}$ and ${ }^{15} \mathrm{~N} /{ }^{14} \mathrm{~N}$ isotope ratios.

Fragments of teeth (Figure 2) and pieces of bones weighing up to several grams were cut off for analyses using a small circular saw with a diamond blade. Only larger fragments of the inner parts of bones and teeth were selected for further processing. Test extractions of collagen from powdered bone and tooth resulted in a very low mass of the obtained collagen, below the limit for accelerator mass spectrometry (AMS) dating. Low yields of collagen in the powdered samples were also reported (Jørkov et al. 2007). The extraction of collagen followed standard procedures (Longin 1971; Piotrowska and Goslar 2002). Additionally, the treatment of samples with $0.025 \mathrm{M} \mathrm{NaOH}$ and ultrafiltration of collagen was introduced (Brown et al. 1998). Although the collected samples of bone and teeth were not exposed directly to hydrocarbons that impregnated the soft tissue, extraction of collagen was preceded by repeated washing of each sample in acetone, alcohol, and water.
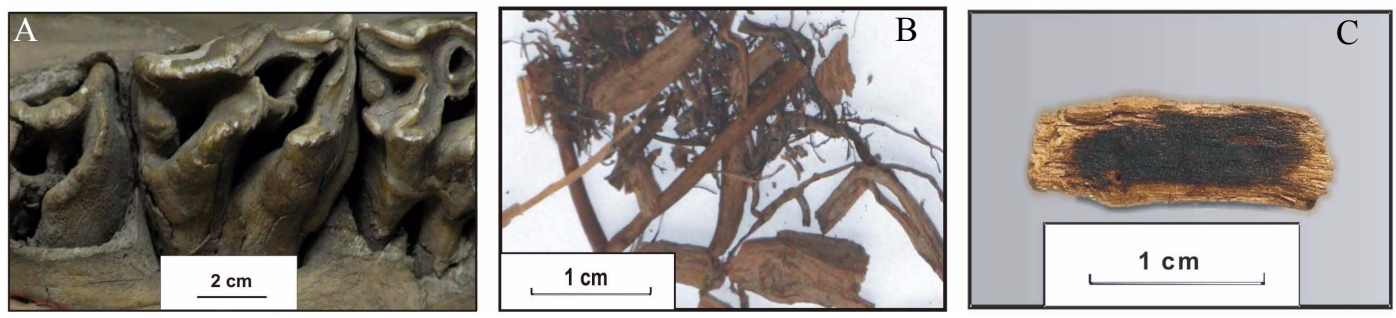

Figure 2 A) Dated teeth of rhinoceros No. 3 (lower jaw); B) Macrofossils retrieved from sediment cores in the Starunia area representing different types of plant material. The sample composed mostly of tiny fragments of green plants; C) Piece of wood with hydrocarbon contamination still visible (dark inner part) after procedure of chemical cleaning. 
Individual macrofossils were visually identified and picked out by hand from the bulk core samples. The following separation procedure was applied: sample of core material $\left(\sim 20 \mathrm{~cm}^{3}\right)$ was immersed in distilled water in a glass pan and plant fragments, after identification, were picked out by tweezers. Organic fragments obtained in that way differed from sample to sample. Some of the separated macrofossils were typical for remnants of small green plants (grass, sedge) while others consisted mainly of broken pieces of sprigs or small branches, resembling material deposited by water (Figure 2). Also, chips of wood originating from bigger fragments, small pieces of bark, or even tiny parts of scales and cuticle were identified. Chemical treatment of the separated macrofossils was aimed at removal of contaminants, mostly of hydrocarbon origin. After initial rinsing with distilled water, the separated macrofossils were oven-dried and left overnight in dichloromethane $\left(\mathrm{CH}_{2} \mathrm{Cl}_{2}\right)$, then rinsed 3-4 times in benzene $\left(\mathrm{C}_{6} \mathrm{H}_{6}\right)$ until disappearance of color, followed by rinsing in acetone for $\sim 5 \mathrm{~min}$, and washing in distilled water. Finally, the samples were oven-dried at $120{ }^{\circ} \mathrm{C}$. Masses of individual macrofossil samples delivered to the AMS laboratory did not exceed $150 \mathrm{mg}$.

In the AMS laboratory, the samples were examined again. As some of the largest fragments of wood revealed the presence of hydrocarbons in their inner part even after the cleaning steps described above (cf. Figure 2), only much smaller pieces of plant remnants were selected for further treatment. The samples were then treated with $4 \% \mathrm{HCl}$ (room temperature, $12 \mathrm{hr}$ ), $0.5 \mathrm{M} \mathrm{NaOH}\left(60{ }^{\circ} \mathrm{C}\right.$, up to $2 \mathrm{hr}$ ), and again $4 \% \mathrm{HCl}$ (room temperature, $2 \mathrm{hr}$ ). Combustion to $\mathrm{CO}_{2}$ was performed in a closed quartz tube together with $\mathrm{CuO}$ and $\mathrm{Ag}$ wool at $900{ }^{\circ} \mathrm{C}$. The $\mathrm{CO}_{2}$ gas was then reduced with $\mathrm{H}_{2}$ over Fe powder as a catalyst $(2 \mathrm{mg})$ and the resulting graphite/iron mixture was pressed into a pellet in the target holder (Czernik and Goslar 2001).

Stable nitrogen and carbon isotope compositions for the collagen samples were analyzed using a Delta Plus mass spectrometer equipped with ConFlo II and an elemental analyzer EA 1108. Samples of $\sim 0.3 \mathrm{mg}$ of collagen were placed in zinc capsules and burned at $1020{ }^{\circ} \mathrm{C}$. Carbon dioxide and nitrogen were separated and introduced into the mass spectrometer for isotope ratio analyses. Typical standard uncertainty of the stable isotope analyses was $0.2 \%$ for carbon and $0.4 \%$ for nitrogen.

${ }^{14} \mathrm{C}$ content in the analyzed samples was measured using a compact carbon AMS machine (Goslar et al. 2004) by comparing simultaneously collected ${ }^{14} \mathrm{C},{ }^{13} \mathrm{C}$, and ${ }^{12} \mathrm{C}$ beams with those of oxalic acid standard $\mathrm{CO}_{2}$, and coal background material. Conventional ${ }^{14} \mathrm{C}$ ages were calculated with $\delta^{13} \mathrm{C}$ correction for isotopic fractionation (Stuiver and Polach 1997), based on the ${ }^{13} \mathrm{C} /{ }^{12} \mathrm{C}$ ratio measured by the AMS system simultaneously with the ${ }^{14} \mathrm{C} /{ }^{12} \mathrm{C}$ ratio. For determination of the measurement uncertainty, both the counting statistics of the ${ }^{14} \mathrm{C}$ analysis and the variability of the intermediate results were observed, and the larger of the 2 values was adopted as the measurement uncertainty. Then, the uncertainty connected with the subtraction of the background was included. The $1 \sigma$ uncertainty quoted in Table 3 is thus our best estimate for the overall uncertainty of the measurement, not based just on the counting statistics alone. Calibrated calendar ages were calculated using OxCal v 4.1.5 (Bronk Ramsey 2009) with atmospheric calibration data from Reimer et al. (2009).

\section{RESULTS AND DISCUSSION}

\section{Stable Carbon and Nitrogen Isotope Composition of Collagen}

Stable nitrogen and carbon isotope content as well as elemental $\mathrm{C} / \mathrm{N}$ ratios were measured in collagen extracted from 4 samples ( 2 bones and 2 teeth) representing woolly rhinoceroses Nos. 1, 2, and 3. The $\mathrm{C} / \mathrm{N}$ ratio varied from 2.4 to 4.4 (Table 3). The measured $\delta^{15} \mathrm{~N}$ values ranged from +3.7 to $+5.4 \%$, showing higher values for teeth than bone, while $\delta^{13} \mathrm{C}$ values oscillated between -22.7 and $-21.2 \%$. Although the generally accepted range of $\mathrm{C} / \mathrm{N}$ ratio indicating good preservation of colla- 


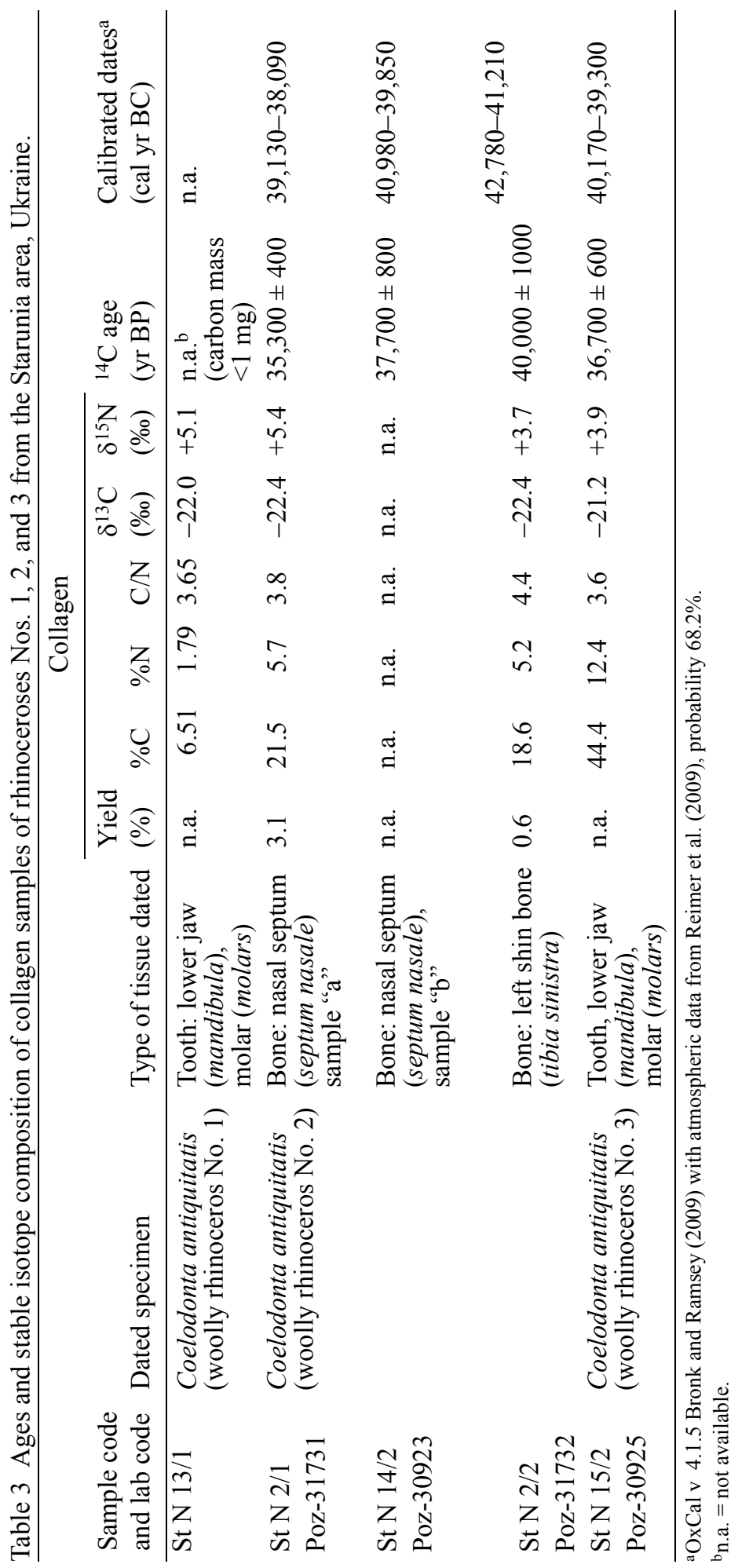


gen is somewhat smaller (from about 2.9 to 3.6; Ambrose 1990), it is believed that potential influence of the degradation of collagen on the measured ${ }^{13} \mathrm{C} /{ }^{12} \mathrm{C}$ and ${ }^{15} \mathrm{~N} /{ }^{14} \mathrm{~N}$ ratios in the analyzed samples is relatively small (Bocherens et al. 1995).

Stable isotope ratios of carbon and nitrogen in fossil bones and teeth collagen are widely used now as a tool in paleoenvironmental and paleodietary studies of Pleistocene mammals. For Europe, the published results include material from Kent's Cavern, Great Britain (Bocherens et al. 1995), and Scladina Cave in Belgium (Bocherens et al. 1997). Also, extensive work has been carried out in North America, on the material from Rancho La Brea, California (Coltrain et al. 2004; O'Keefe at al. 2009), and in Siberia, on the material from Yakutia (Bocherens et al. 1996).

The $\delta^{15} \mathrm{~N}$ and $\delta^{13} \mathrm{C}$ values obtained for collagen extracted from bones and teeth belonging to rhinoceroses Nos. 1, 2, and 3 from Starunia are shown in Figure 3 together with available literature data for large Pleistocene mammals from Kent's Cavern (14 samples of rhinoceroses), Scladina Cave (6 samples of rhinoceroses and 3 samples of mammoth), La Brea (7 samples of mammoth), and Yakutia (1 sample of rhinoceros and 11 samples of mammoths). Although the isotope data from 5 presented localities broadly overlap within a relatively narrow area, with $\delta^{15} \mathrm{~N}$ values ranging from $\sim 3.7$ to $9.5 \%$ and $\delta^{13} \mathrm{C}$ values from -22.9 to $-19.8 \%$, some systematic differences, particularly for $\delta^{15} \mathrm{~N}$, are apparent. The $\delta^{15} \mathrm{~N}$ values for collagen of the Starunia samples are in the range observed for woolly rhinoceroses from the Kent's Cavern and from La Brea, slightly lower than for Scladina Cave, and remarkably lower than for mammoths from Yakutia. With respect to $\delta^{13} \mathrm{C}$, the Starunia values fall into the range for the Kent's Cavern and Yakutia samples, being distinctly more negative than the samples from Scladina Cave and from La Brea site. The observed differences most probably stem from regional differences in isotopic composition of plant habitat, which was the source of food for those animals, as well as other factors related to local environment, such as $\mathrm{C}_{3} / \mathrm{C}_{4}$ composition of local plant communities, controlled by climate and continentality of the given site.

\section{Radiocarbon Dating of Bones and Teeth}

In the framework of the present study, 4 AMS ${ }^{14} \mathrm{C}$ dates were obtained: (i) 2 dates for a bone from the nasal septum and 1 date for a bone from the left shin, all 3 representing woolly rhinoceros No. 2 , and (ii) 1 date for woolly rhinoceros No. 3 (tooth, lower jaw). A tooth sample representing rhinoceros No. 1 was also collected, but the amount of collagen obtained was too small for ${ }^{14} \mathrm{C}$ analysis (only determination of ${ }^{13} \mathrm{C} /{ }^{12} \mathrm{C}$ and ${ }^{15} \mathrm{~N} /{ }^{14} \mathrm{~N}$ ratios was made). The results are reported in Table 3. In Table 2, earlier attempts to date the specimens analyzed in the present study are summarized.

Three ${ }^{14} \mathrm{C}$ dates obtained on woolly rhinoceros No. 2 span from 35.3 to $40.0 \mathrm{ka} \mathrm{BP}$. The corresponding calibrated ages (cal BP) range from 38.1 to $42.8 \mathrm{ka}, 68.2 \%$ probability (Table 3, Figure 4 ). The mean calendar age is $40.1 \pm 0.4 \mathrm{ka} \mathrm{cal} \mathrm{BP}$. The ${ }^{14} \mathrm{C}$ age of rhinoceros No. 3 is $36.7 \pm 0.6 \mathrm{ka}$ and the corresponding calibrated age ranges from 39.3 to $40.2 \mathrm{ka}$ cal BP. This places the presumable calendar age of paleontological findings from Starunia somewhere between 39 and $41 \mathrm{ka} \mathrm{BP}$.

Attempts to date paleontological findings from the Starunia site go back to early 1970s. The results obtained before 2006 are confusing (Kuc et al. 2005). Previously obtained ${ }^{14} \mathrm{C}$ ages reported for the specimens dated within the present study vary widely, from $\sim 14$ ka for woolly rhinoceros No. 1 up to $\sim 47 \mathrm{ka}$ for rhinoceros No. 2 (cf. Table 2). It is apparent from Tables 1 and 2 that conventional dating methods (gas counting; benzene synthesis combined with liquid scintillation spectrometry) requiring much larger mass of sample were yielding generally too-low ${ }^{14} \mathrm{C}$ ages when compared to the AMS technique. 


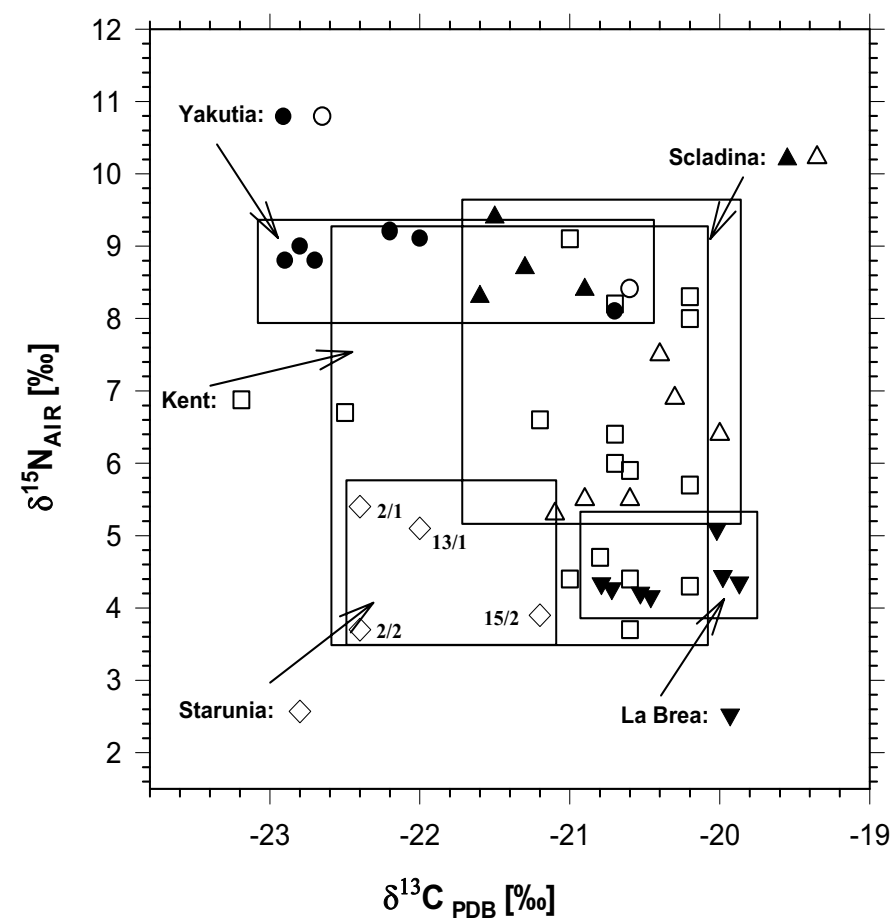

Figure 3 Relationship between $\delta^{15} \mathrm{~N}$ and $\delta^{13} \mathrm{C}$ values of collagen extracted from 4 samples ( 2 bones and 2 teeth) representing woolly rhinoceroses remnants found in the Starunia area, Ukraine (symbols indicate no. of sample), compared to other data of rhinoceroses and mammoths from different locations in North America, Europe, and Asia: La Brea (Coltrain et al. 2004); Kent (Bocherens et al. 1995); Scladina Cave (Bocherens et al. 1997); and Yakutia (Bocherens et al. 1996) . Rhinoceroses $=$ open symbols; mammoths $=$ filled black symbols. Numbers next to the symbols of Starunia samples correspond to numbers listed in Table 3.

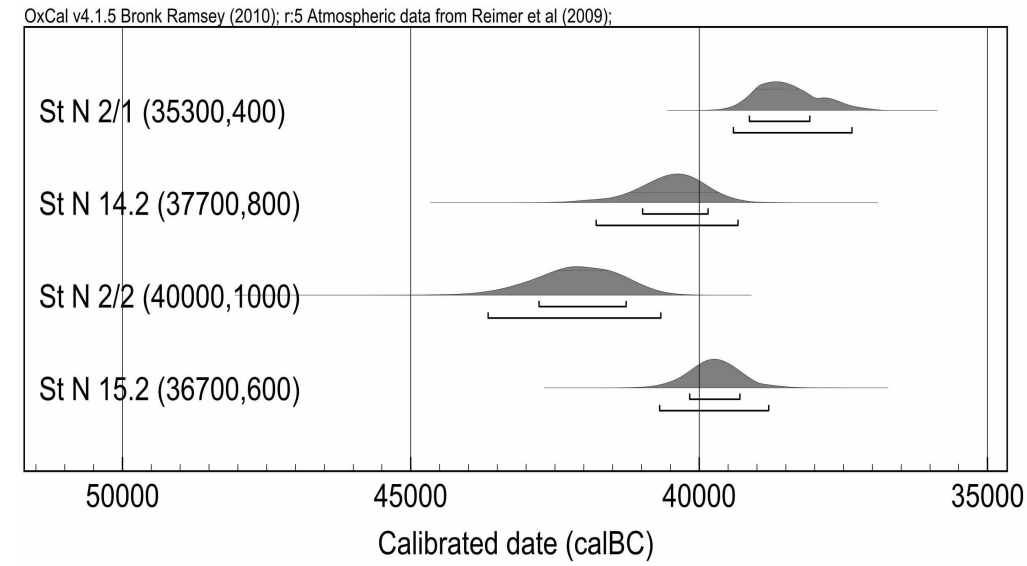

Figure 4 Calibrated ages of woolly rhinoceroses No. 2 and No. 3 from the Starunia area, Ukraine. Calibration done using OxCal v 4.1.5 (Bronk Ramsey 2009) with atmospheric data from Reimer et al. (2009). 
Although it is very difficult to pinpoint specific reason(s) for the observed large discrepancies in ${ }^{14} \mathrm{C}$ dates obtained over the years for the specimens dated in the framework of the present study, some general factors related to specific characteristics of the local environment in which the dated specimens were preserved, as well as to postexcavation history of those specimens, can be identified. A detailed discussion of this issue is given in Kuc et al. (2005), only a brief outline of which is presented below.

On one hand, remnants of woolly rhinoceroses found at Starunia site were buried for thousands of years in a peculiar environment where oil and earth wax were present. In addition, concentrated brines occurring in the area could have penetrated into the dated material. Since oil is free of ${ }^{14} \mathrm{C}$, the specific problem of vital importance for ${ }^{14} \mathrm{C}$ dating Starunia samples is a complete removal of contamination by dead carbon of allochthonous origin. Incomplete removal of ${ }^{14} \mathrm{C}$-free hydrocarbons from the dated material would then lead to too-high ages. On the other hand, the remnants of rhinoceroses found at Starunia were preserved after excavation with the aid of various organic materials containing contemporary ${ }^{14} \mathrm{C}$. For instance, organic "bone glue" consisting mostly of collagen was used to fix broken parts of bones. Such glue was also used to preserve the skin and other soft parts of the excavated specimens. It is obvious that such preservation techniques introduced large amounts of contemporary carbon into the specimens further exposed in museums. This concerns particularly rhinoceros No. 2. Consequently, relatively young ${ }^{14} \mathrm{C}$ ages of Starunia paleontological findings obtained in the past on soft tissues (skin), might have its origin in incomplete removal of contemporary carbon during sample preparation.

\section{Radiocarbon Dating of Macrofossils}

Multidisciplinary studies performed in Starunia between 2006 and 2009 were confined to the area of an abandoned mine of earth wax and extended over a surface of $\sim 10.5$ ha, including in its center the place of mining works leading to the discovery of the rhinoceros carcass in 1929. In total, 44 boreholes (Figure 1) were drilled to depths from 4.6 to $20.0 \mathrm{~m}$ during the 2007-2008 field campaigns and $191.2 \mathrm{~m}$ of cores of Quaternary sediments were retrieved for further investigations (Kotarba 2009a,b). ${ }^{14} \mathrm{C}$ dating of plant macrofossils retrieved from sediment cores allowed an insight into the age structure of Quaternary sediment cover directly at the site of paleontological discoveries, thus providing a broader context for the dated remnants of fossil fauna of the burial site (Kuc et al. 2009).

Table $4{ }^{14} \mathrm{C}$ dates of plant macrofossils obtained from sediment cores retrieved close to the site of discovery of rhinoceroses remnants at Starunia.

\begin{tabular}{lllccl}
\hline No. & Description & $\begin{array}{l}\text { Sample code } \\
\text { Lab code } \mathrm{nr}\end{array}$ & $\begin{array}{l}{ }^{14} \mathrm{C} \text { age } \\
\text { (yr BP) }\end{array}$ & $\begin{array}{l}\text { Calibrated age } \\
\text { (cal yr BP) }\end{array}$ & Probability \\
\hline 1. & $\begin{array}{l}\text { Borehole 30: } \\
\text { depth 2.50 m }\end{array}$ & $\begin{array}{l}\text { St 30/38 } \\
\text { Poz-28903 }\end{array}$ & $5490 \pm 40$ & $6320-6270$ & $53.1 \%^{\mathrm{a}}$ \\
2. & $\begin{array}{l}\text { Borehole 30: } \\
\text { depth 6.80 m }\end{array}$ & $\begin{array}{l}\text { St 30/02 } \\
\text { Poz-26617 }\end{array}$ & $48,200 \pm 1800$ & $50,380-46,490^{\mathrm{b}}$ & $68.2 \%$ \\
3. & $\begin{array}{l}\text { Borehole 42: } \\
\text { depth 3.90 m }\end{array}$ & $\begin{array}{l}\text { St 42/29 } \\
\text { Poz-28806 }\end{array}$ & $230 \pm 30$ & $300-320$ & $35.8 \%$ \\
4. & $\begin{array}{l}\text { Borehole 42: } \\
\text { depth 9.50-9.60 m }\end{array}$ & $\begin{array}{l}\text { St 42/40 } \\
\text { Poz-29312 }\end{array}$ & $16,260 \pm 80$ & $19,450-19,260$ & $54.5 \%$ \\
5. & $\begin{array}{l}\text { Borehole 42: } \\
\text { depth 9.70-9.80 m }\end{array}$ & $\begin{array}{l}\text { St 42/30 } \\
\text { Poz-28807 }\end{array}$ & $22,900 \pm 150$ & $28,030-27,560^{\mathrm{b}}$ & $61.4 \%$ \\
\hline
\end{tabular}

${ }^{a}$ Very high content of hydrocarbons in the sample.

${ }^{b}$ Date out of range. 
The ${ }^{14} \mathrm{C}$ dating results of plant macrofossils retrieved from cores 30 and 42 are presented in Table 4 and shown in Figure 5. These cores are of direct relevance for the results of age determination of woolly rhinoceroses remnants discussed above as they provide an insight into the sequence of layers in close vicinity of the gallery where rhinoceros No. 2 was found (cf. Figure 1).

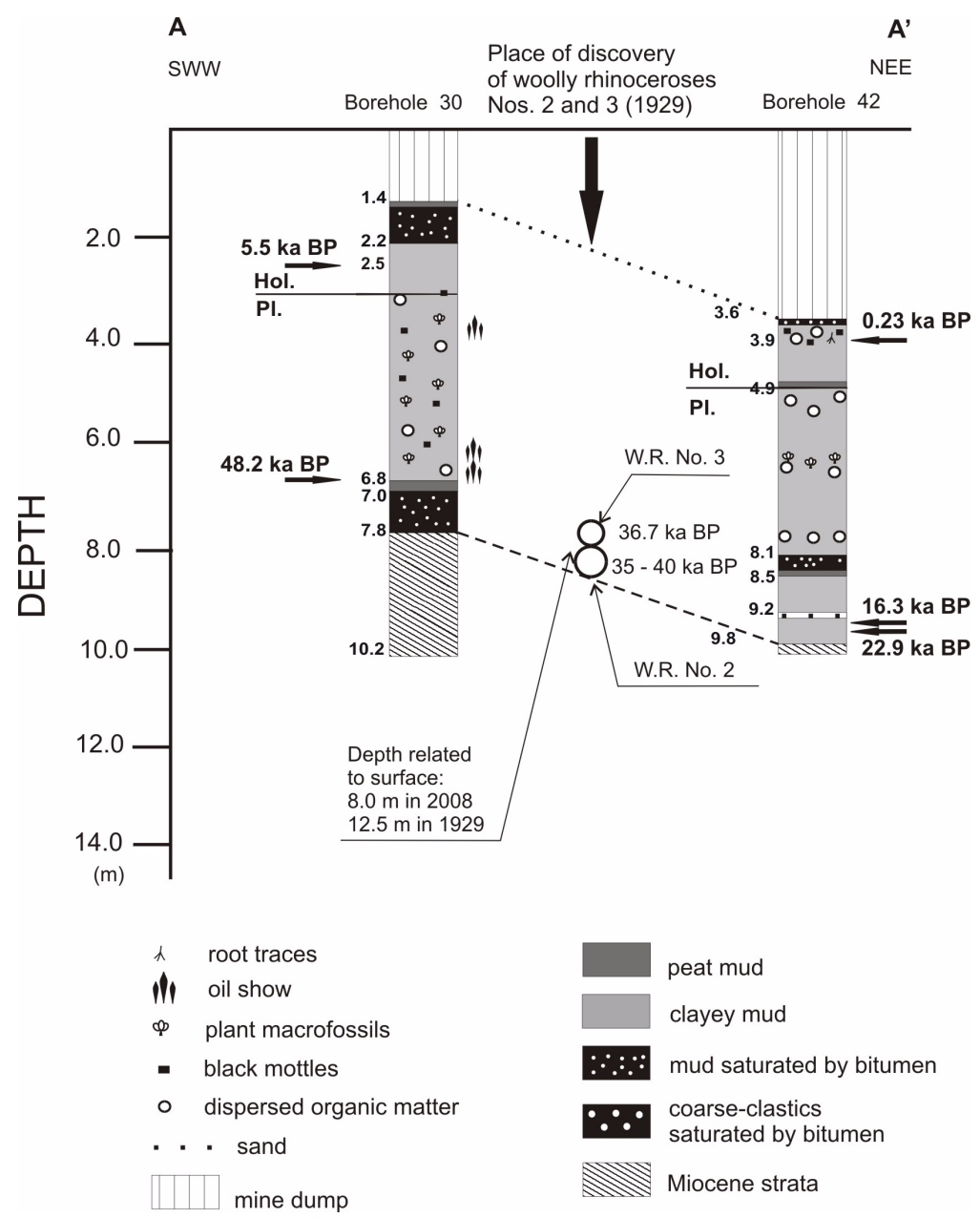

Figure 5 Lithological structure of Quaternary sediments in the immediate surroundings of the discovery site of woolly rhinoceroses remnants in the Starunia area. Shown are 2 sediment profiles (borehole 30 and 42, cf. Figure 1). The dashed line shows schematically the present position of the top of Miocene strata, whereas the dotted line represents the bottom of the mine dump along the A-A' cross-section. Position of ${ }^{14} \mathrm{C}$-dated macrofossils retrieved from the sediment cores is marked by horizontal arrows: W.R. - woolly rhinoceros; Pl. - Pleistocene; Hol. - Holocene.

Cores 30 and 42 lay directly on the cross-section line A-A' shown in Figure 1, $\sim 50$ and $30 \mathrm{~m}$, respectively, from the place of the discovery of rhinoceros No. 2. The 2 cores cover the entire sequence of Quaternary deposits on the site. The uppermost layer in each core consists of reworked mine dump. The Pleistocene/Holocene boundary was identified in each core through palynological studies (Stachowicz-Rybka et al. 2009). The boundary is placed at $\sim 3.0 \mathrm{~m}$ depth in core 30 and at $\sim 4.9 \mathrm{~m}$ depth in core 42. Clayey mud with macrofossils is present in both profiles. It was deposited during the gla- 
cial period and is separated from the top of the Miocene strata by peat mud and mud saturated with bitumen (borehole 30), or rests directly on the top of the Miocene (borehole 42). The top of the Miocene strata is located at $7.8 \mathrm{~m}$ in core 30 and at $9.8 \mathrm{~m}$ in core 42. Stach (1930) reported that woolly rhinoceros No. 2 was found at the depth $\sim 12.5 \mathrm{~m}$, lying in upside down position directly in contact with Quaternary sediments with Miocene clays. Morphostructural studies performed on the core material obtained during the 2006-2009 field campaigns in the area suggest that significant displacement of material took place at the surface since the time of discovery of rhinoceros No. 2 (Sokołowski et al. 2009). It is very likely that part of the mine dump was removed during mining works in the Starunia ozocerite mine 1929-1960, leading to reduced depth intervals from the local surface, when compared to the first quarter of the 20th century.

The ${ }^{14} \mathrm{C}$ ages of plant remnants retrieved from cores 30 and 42 span from 230 to $48.2 \mathrm{ka} \mathrm{BP}$. Macrofossils representing the deepest layer in each core reveal large differences in ${ }^{14} \mathrm{C}$ ages: $\sim 22.9 \mathrm{ka} \mathrm{BP}$ for core 42 and 48,200 yr BP for core 30. These differences suggest enhanced fluvial activity in the retrieval place of core 42 , which ceased around the time indicated by dated macrofossils in this core. Averaging the 2 ages indicated above one arrives at $\sim 35.0 \mathrm{ka} \mathrm{BP}$ as a rough lower limit of the ${ }^{14} \mathrm{C}$ age of Pleistocene fauna discovered at Starunia site.

\section{CONCLUSION}

Decades of applications of ${ }^{14} \mathrm{C}$ dating place possible contamination of the dated material by allochthonous carbon among the most critical issues having direct impact on reliability of the method. An example of such a problem is provided by the repeated attempts to date remnants of large Pleistocene mammals, including a complete carcass of woolly rhinoceros, discovered in Starunia, southwest Ukraine, at the beginning of 20th century.

This new attempt to date Starunia paleontological findings relied on AMS dating of collagen retrieved from carefully selected inner parts of bones and teeth of rhinoceroses remnants, preceded by cleaning of the samples. A thorough, multistep purification procedure adopted in this case was aimed at removing 2 potential sources of contamination: (i) ${ }^{14} \mathrm{C}$-free hydrocarbons (oil and earth wax) abundant at the burial site; and (ii) allochthonous organic materials (mostly "bone glue") containing contemporary carbon, which were used in the past during preservation of the dated specimens. This new attempt to date the remnants of woolly rhinoceroses discovered in Starunia was accompanied by ${ }^{14} \mathrm{C}$ dating of terrestrial macrofossils collected from sediment cores retrieved in the immediate vicinity of the burial site.

The ${ }^{14} \mathrm{C}$ dates obtained for woolly rhinoceros No. 2 range from 35.3 to $40.0 \mathrm{ka} \mathrm{BP}$, in agreement with the minimum age estimated from macrofossils. The mean value of $37.7 \pm 1.7 \mathrm{ka} \mathrm{BP}$ falls in the range of ages reported for big Pleistocene mammals from other locations in Europe (Stuart and Lister 2007; Kuzmin 2010). The lack of some inner organs and a big cut on the abdominal side of woolly rhinoceros No. 2 point to transportation by water before final deposition. ${ }^{14} \mathrm{C}$-dated bones of rhinoceros No. 3 that were found near rhinoceros No. 2 reveal an age of $36.7 \pm 0.6 \mathrm{ka}$ BP. Although indistinguishable in age, the history of both rhinoceroses was probably quite different. In contrast to rhinoceros No. 2, only bones soaked with earth oil (creating a chaotic mixture not resembling skeleton form) were found for rhinoceros No. 3, without any soft tissue. It is very probable that those bones were also redeposited. 


\section{ACKNOWLEDGMENTS}

Financial support of this work from the Ministry of Science and Higher Education through project No. 139/UKR/2006/01 as well as through statutory funds of the AGH University of Science and Technology (projects Nos. 11.11.140.560 and 11.11.220.01) is kindly acknowledged. We are grateful to T Kowalski for analytical work related to stable isotope analyses of collagen. We thank Dr Y Kuzmin for his thorough review of the manuscript and valuable suggestions for improving it.

\section{REFERENCES}

Adamenko OM, Stelmakh OR, Zinchuk MS, Kotarba MJ. 2005. History of petroleum exploration in the Starunia area, fore-Carpathian region, Ukraine. In: Kotarba MJ, editor. Polish and Ukrainian Geological Studies in the Years 2004-2005 at Starunia - The Area of Discoveries of Woolly Rhinoceroses and Other Extinct Vertebrates. Warsaw-Kraków: Polish Geological Institute and "Geosphere." p 53-60.

Alexandrowicz SW. 2004. Starunia i badaniya chvartozhedu v tradycjy i inicyatyvah Polskey Akadmi Nauk [Starunia and the Quaternary research in the tradition and initiatives of the Polish Academy of Arts and Sciences]. Studia i materiały do dziejów PAU 3: 261.

Alexandrowicz SW. 2005. The history of Starunia - a palaeontologic site and old ozocerite mine. In: Kotarba MJ, editor. Polish and Ukrainian Geological Studies in the Years 2004-2005 at Starunia - The Area of Discoveries of Woolly Rhinoceroses and Other Extinct Vertebrates. Warsaw-Kraków: Polish Geological Institute and "Geosphere." p 21-36.

Ambrose SH. 1990. Preparation and characterization of bone and tooth collagen for isotopic analysis. Journal of Archaeological Sciences 17(4):431-51.

Bayger JA, Hoyer H, Kiernik E, Kulczyński W, Łomnicki M, Łomnicki J, Mierzejewski W, Niezabitowski E, Raciborski M, Szafer W, Schille F. 1914. Wykopalyska Starunske [Excavations in Starunia]. Muzeum im. Dzieduszyckich we Lwowie 15:386.

Bocherens H, Fogel ML, Tuross N, Zender M. 1995. Trophic structure and climatic information from isotopic signatures in Pleistocene cave fauna of southern England. Journal of Archaeological Science 22(2): $327-40$.

Bocherens H, Pacaud G, Lazarev PA, Mariotti A. 1996. Stable isotope abundances $\left({ }^{13} \mathrm{C},{ }^{15} \mathrm{~N}\right)$ in collagen and soft tissues from Pleistocene mammals from Yakutia: implications for the palaeobiology of the Mammoth Steppe. Palaeogeography, Palaeoclimatology, Palaeoecology 126(1-2):31-44.

Bocherens H, Billiou D, Patou-Mathis M, Bonjean D, Otte M, Mariotti A. 1997. Paleobiological implications of the isotopic signatures $\left({ }^{13} \mathrm{C},{ }^{15} \mathrm{~N}\right)$ of fossil mammal collagen in Scladina Cave (Sclyn, Belgium). Quaternary Research 48(3):370-80.

Bronk Ramsey C. 2009. Bayesian analysis of radiocarbon dates. Radiocarbon 51(1):337-60.
Brown TA, Nelson DE, Vogel JS, Southon JR. 1988. Improved collagen extraction by modified Longin method. Radiocarbon 30(2):171-7.

Coltrain JB, Harris JM, Cerling TE, Ehleringer JR, Dearing M-A, Ward J, Allen J. 2004. Rancho La Brea stable isotope biogeochemistry and its implications for the palaeoecology of late Pleistocene, coastal southern California. Palaeogeography, Palaeoclimatology, Palaeoecology 205(3-4):199-219.

Czernik J, Goslar T. 2001. Preparation of graphite targets in the Gliwice Radiocarbon Laboratory for AMS ${ }^{14} \mathrm{C}$ dating. Radiocarbon 43(2A):283-91.

Duliński M, Różański K, Kotarba MJ. 2005. Isotopic and chemical composition of surface and groundwaters in the Starunia area, fore-Carpathian region, Ukraine. In: Kotarba MJ, editor. Polish and Ukrainian Geological Studies in the Years 2004-2005 at Starunia - The Area of Discoveries of Woolly Rhinoceroses and Other Extinct Vertebrates. Warsaw-Kraków: Polish Geological Institute and "Geosphere." p p 187-94.

Goslar T, Czernik J, Goslar E. 2004. Low-energy ${ }^{14} \mathrm{C}$ AMS in Poznań Radiocarbon Laboratory, Poland. $\mathrm{Nu}$ clear Instruments and Methods in Physics Research Section B 223-224:5-11.

Jørkov MLS, Heinemeier J, Lynnerup N. 2007. Evaluating bone collagen extraction methods for stable isotope analysis in dietary studies. Journal of Archaeological Science 34(11):1824-9.

Koltun YV, Dudok IV, Kotarba MJ, Adamenko OM, Pavlyuk MI, Burzewski W, Stelmach OK. 2005. Geological setting and petroleum occurrence of the Starunia area, Fore-Carpathians region, Ukraine. In: Kotarba MJ, editor. Polish and Ukrainian Geological Studies in the Years 2004-2005 at Starunia - The Area of Discoveries of Woolly Rhinoceroses and Other Extinct Vertebrates. Warsaw-Kraków: Polish Geological Institute and "Geosphere." p 61-78.

Kotarba MJ. 2002. Composition and origin of hydrocarbons saturating the remnants of woolly rhinoceros from Starunia, the Ukrainian Carpathians. Przeglad Geologiczny 50:531-4.

Kotarba MJ, editor. 2005. Polish and Ukrainian Geological Studies in the Years 2004-2005 at Starunia - The Area of Discoveries of Woolly Rhinoceroses and Other Extinct Vertebrates. Warsaw-Kraków: Polish Geological Institute and "Geosphere."

Kotarba MJ, editor. 2009a. Interdisciplinary studies 
(2006-2009) at Starunia (Carpathian Region, Ukraine) - the area of discoveries of woolly rhinoceroses. Annales Societatis Geologorum Poloniae 79(3).

Kotarba MJ. 2009b. Interdisciplinary studies at Starunia palaeontological site and vicinity (Carpathian region, Ukraine) in the years 2006-2009: previous discoveries and research, purposes, results and perspective. Annales Societatis Geologorum Poloniae 79:219-41.

Kotarba MJ, Koltun YV. 2006. The origin and habitat of hydrocarbons of the Polish and Ukainian parts of the Carpathian Province. In: Golonka J, Picha FJ, editors. The Carpathians and Their Foreland: Geology and Hydrocarbon Resources. American Association of Petroleum Geologists Memoir 84:395-442.

Kotarba MJ, Więcław D, Toboła T, Zych H, Kowalski A, Ptak S. 2009. Bitumen and salt contents within the Quaternary sediments at Starunia palaeontological site and vicinity (Carpathian region, Ukraine). $A n-$ nales Societatis Geologorum Poloniae 79:447-61.

Kubiak H. 1971. Datovaniya radioveglem ${ }^{14} \mathrm{C}$ shtchontkov nosoroschca wlokchatego ze Staruni [Radiocarbon dating of the remnants of a woolly rhinoceros from Starunia]. Wsześchwiat 10:267-8.

Kubiak H. 2003. Nosoroschce i mamut ze Staruni [Woolly rhinoceroses and mammoth from Starunia. Pr. Komis. Paleogeogr. Czwartorzędu PAU 1:19-20.

Kubiak H, Drygant DM. 2005. The Starunia collections in Lviv and Kraków natural history museums and history of palaeontological studies. In: Kotarba MJ, editor. Polish and Ukrainian Geological Studies in the Years 2004-2005 at Starunia - The Area of Discoveries of Woolly Rhinoceroses and Other Extinct Vertebrates. Warsaw-Kraków: Polish Geological Institute and "Geosphere." p 37-44.

Kuc T, Różański K, Goslar T, Kubiak H, Kotarba MJ 2005. Radiocarbon dating of remnants of woolly rhinoceroses and mammoth from Starunia, fore-Carpathians, Ukraine. In: Kotarba MJ, editor. Polish and Ukrainian Geological Studies in the Years 2004-2005 at Starunia - The Area of Discoveries of Woolly Rhinoceroses and Other Extinct Vertebrates. WarsawKraków: Polish Geological Institute and "Geosphere." p 195-202.

Kuc T, Różański K, Goslar T, Stachowicz-Rybka R. 2009. Radiocarbon dating of plant remnants in Quaternary sediments at Starunia palaeontological site and vicinity (Carpathian region, Ukraine). Annales Societatis Geologorum Poloniae 79:289-96.

Kuzmin YV. 2010. Extinction of woolly mammoth (Mammuthus primigenius) and woolly rhinoceros (Coelodonta antiquitatis) in Eurasia: review of chronological and environmental issues. Boreas 39(2): 247-61.

Longin R. 1971. New method of collagen extraction for radiocarbon dating. Nature 230(5291):241-2.

O'Keefe FR, Fet EV, Harris JM. 2009. Compilation, calibration, and synthesis of faunal and floral radiocarbon dates, Rancho La Brea, California. Contribution in Science, Number 518, Natural History Museum of Los Angeles County. p 1-16.

Piotrowska N, Goslar T. 2002. Preparation of bone samples in the Gliwice Radiocarbon laboratory for AMS radiocarbon dating. Isotopes in Environmental Health Studies 38 (4):267-75.

Reimer PJ, Baillie MGL, Bard E, Bayliss A, Beck JW, Blackwell PG, Bronk Ramsey C, Buck CE, Burr GS, Edwards RL, Friedrich M, Grootes PM, Guilderson TP, Hajdas I, Heaton TJ, Hogg AG, Hughen KA, Kaiser KF, Kromer B, McCormac FG, Manning SW, Reimer RW, Richards DA, Southon JR, Talamo S, Turney CSM, van der Plicht J, Weyhenmeyer CE. 2009. IntCa109 and Marine09 radiocarbon age calibration curves, 0-50,000 years cal BP. Radiocarbon 51(4): $1111-50$.

Sokołowski T, Stachowicz-Rybka R, Woronko B. 2009. Upper Pleistocene and Holocene deposits at Starunia palaeontological site and vicinity (Carpathian region, Ukraine). Annales Societatis Geologorum Poloniae 79:255-78

Stach J. 1930. The second woolly rhinoceros from the diluvial strata of Starunia. In: Nowak J, Panow E, Tokarski J, Szafer W, Stach J, editors. The Second Woolly Rhinoceros (Coelodonta antiquitatis Blum.) from Starunia, Poland (Geology, Mineralogy, Flora and Fauna). Bulletin International de L'Academie Polonaise des Sciences et des Lettres, Class des Sciences Mathematiques et Naturelles, Serie B: Sciences Naturelles, No Supplementaire. p 21-47.

Stachowicz-Rybka R, Granoszewski W, HrynowieckaCzmielewska A. 2009. Quaternary environmental changes at Starunia palaeontological site and vicinity (Carpathian Region, Ukraine) based on palaeobotanical studies. Acta Societatis Geologorum Poloniae 79: 279-88.

Stuart AJ, Lister AM. 2007. Patterns of Late Quaternary megafaunal extinctions in Europe and northern Asia. Courier Forchungsinstitut Senckenberg 259:287-97.

Stuiver M, Polach H. 1997. Discussion: reporting of ${ }^{14} \mathrm{C}$ data. Radiocarbon 19(3):355-63.

Sulerzitsky LD. 1997. Cherty radiouglerodnoi khronologii mamontov Sibiri i severa Vosochnoi Evropy (kak substrata dlya rasseleniya cheloveka) [Patterns of radiocarbon chronology of mammoths from Siberia and northern Eastern Europe (as substratum for human dispersal]. In: AA Velichko, O Soffer, editors. Chelovek Zaselyaet Planetu Zemlya. Moscow: Institute of Geography, Russian Academy of Sciences. p 184-200. 